\title{
CROSS CULTURAL ISSUES INVOLVED IN AN APPOINTED COMMITTEE MANAGING AN ARAB LOCAL AUTHORITY IN CRISIS IN ISRAEL
}

\author{
Mati AVNI ${ }^{3}$, MA \\ matiavni@walla.com
}

\section{DOI:10.24193/OJMNE.2017.24.03}

\begin{abstract}
The Israeli government appoints committees to manage failing local authorities based on the assumption that failure was due to deterioration in human resources, expressed in lack of managerial skills. Additionally, many times a committee comprised of members from one culture are appointed to manage a local authority from another culture. The purpose of this article is to present partial findings emerging from a qualitative research that focused on cross-cultural factors involved in the management of those failing Arab local authorities managed by Jewish committee members. The findings show that culture embodies a significant component in the committees' practice. Therefore appointed committees wishing to succeed in rehabilitating failing local authorities should strive to bridge the culture gap.
\end{abstract}

Keywords: cross-cultural processes, intercultural negotiation, managing local authority, appointed committee, culture gap.

\section{Introduction}

This article is based on a research that examined cross-cultural issues involved in the management of failing Arab local authorities managed by an appointed committee chaired by a Jewish member. The Israeli government appoints committees to manage failing local authorities based on the assumption that failure was due to deterioration in human resources,

\footnotetext{
${ }^{3}$ For 17 years I have filled various public roles such as heading appointed committees, municipality director general and accountant accompanying Poor Performing local authorities. In the last six years I have been serving as the head of an appointed committee in Mas'ade, in Arab (Druze) village in the Golan Heights, the north of Israel. MA in Public Management and Political Sciences, Bar-Ilan University, Israel; BA in Business Administration and Public Administration, Toro College, USA; BA in Law, Ono academic Center, Israel.
} 
Issue no. $24 / 2017$

expressed in lack of managerial skills. It is commonly assumed that committees are appointed in order to rehabilitate failing local authorities' economic situation (Beeri, 2009). This article attempts to illuminate the cultural and intercultural aspects involved in managing a failing public organization.

As of the 1980's, public organizations in general and local authorities in particular have been subject to structural changes resulting from a comprehensive reform known as "New Public Management" (Ben-Elia, 2005; Christensen, Laegrreid \& Stigen, 2004). Local government in Israel has reached a state of acute economic crisis, which includes the collapse of services in some local authorities. In response, the central government has, inter alia, increased financial supervision of local authorities, and in extreme cases, replaced leadership and senior management in its entirety, or in part, with an appointed committee (Ben-Bassat \& Dahan, 2008; Beeri, 2009).

This approach is based on the assumption that failure is mostly the outcome of deterioration in a local authority's human capital, expressed in leaders and managers who lack management, leadership and political qualifications required for proper management of local authorities (Schendler, 1975; Grinyer, 1990; Mellahi, 2004). In this sense, the Israeli perception regarding failing local authorities derives from an ongoing, sharp decline in internal organizational resources, such as lack of leadership, lack of flexibility, failing financial management, and lack of motivation among local authority workers.

The question with regard to assigning appointed committees is controversial: on the one hand, the ousting of a local authority leader, or the whole leadership, by the Minister of the Interior, directly harms the democratic principle of the right to vote. Residents have the basic right to choose their representatives to lead their settlement. On the other hand, central government has a responsibility to those same residents, primarily with regard to guaranteed provision of appropriate services, including various public services, and for this reason central government has the authority to intervene and even dismiss elected local government. There are those who argue that this policy is likely to encourage a majority in a local authority not to support its leader, and as such bring about elections at any given moment.

An appointed committee is a committee formed to carry out the tasks of a local authority leader and the local authority. It comprises public figures and experts who fulfill the 
roles of the leader and members of the local authority, following a decision and appointment by the Minister of the Interior. This strategy is only used in exceptional cases when the leader of a local authority and/or the local authority as a whole are not functioning as required, and this substantially harms its ability to manage the organization.

In a comprehensive survey that was initiated by the Israeli government, Beeri and Kohel (2009) argued that designating an appointed committee is not an ideal or natural step, but provides a golden opportunity to heal the authority. They pointed out a number of reasons for this opportunity: firstly, an appointed committee is not responsible for the failure. Secondly, it is not tied to outdated traditions. The abilities of the members of the committee are proven and they have no local political aspirations. In addition, an appointed committee earns a high level of legitimization from central government. Moreover, they examined the influence of assigning an appointed committee on the democratic deficit of local authorities. The democratic deficit is defined as the gap between what exists and what is fitting, that is to say, between a local authority being a democratic institution to some extent, but not sufficiently so. The deficit can result from disappointment in a local authority's functioning, from the way in which it makes decisions or the quality of its services. Symptoms of the deficit can be withdrawal from political participation, despair and lack of belief in an organization and its leadership. According to Beeri and Kohel (2009), designating an appointed committee is the final formal expression of central government's disillusion in the functioning of a local authority and lack of belief in its ability to rehabilitate itself.

Hence, this situation challenges the policy of coping with poor performing local authorities in Israel, from an intercultural point of view. This article focuses on one Arab local authority in Israel that was run by an appointed committee comprising of Jewish members and also was chaired by a Jewish member. Thus, the article provides a unique outlook on a cross-cultural process and ultimately offers insights that can help in developing a framework for managing local organizations within an intercultural context in a globalized era.

\section{Literature Review}

As mentioned earlier, appointed committees are assigned to fulfill the roles of local authorities and their leaders. In general, it can be said that the designation of an appointed 
committee takes place when a local authority demonstrates general dysfunction, shows heavy deficits or sets and collects too little local rates and taxes, fails to carry out recovery plans or to agree on a budget. As well as cases where such appointed committees have balanced the books and successfully provided local services, the need for and suitability of this policy have been criticized from the points of view of feasibility and democracy.

That is to say, from an applied perspective, there are no structural mechanisms for these appointed committees except for a decision to establish them, their supervision and inspection and an overall view of their workings, which is recovery programs and public participation (Ben-Bassat \& Dahan, 2008). There is a distinct lack of clear and systematic procedures to nurture failing local authorities. Additionally, from the democracy standpoint, affected citizens' preferences should be strengthened and they should be able to take responsibility for what is happening in their local authority.

In a cross-cultural context, intercultural needs to be dialogue is employed. An intercultural dialogue is understood as 'the exchange of views and opinions between different cultures'. Thus, an intercultural dialogue seeks to establish linkage and common ground between different cultures, communities, and people, promoting understanding and interaction (EU Council, in Puscas, 2009). In the intercultural context under the investigation of this study, communication seems a critical factor for managing an organization. More specifically, intercultural communication needs to be employed, and views need to be exchanged respectfully between the parties involved who are different in terms of religion, language, and heritage (Puscas, 2009). This study concerns with a dialog maintained between the appointed committee belonging to one culture and the organization which belongs to another culture.

No research has been found that addresses the intercultural processes involved in an appointed committee comprised of members from one culture managing a public organization from another culture, hence the significance of this research. Thus, the aim of the study was to explore the cross-cultural issues involved in managing an Arab local authority by an appointed committee whose members' culture is different than the culture of the local authority. 
Issue no. $24 / 2017$

\section{Methodology}

A qualitative research approach was employed to understand the cross-cultural issues involved in managing an Arab local authority by an appointed committee whose members' culture is different than the culture of the local authority. A qualitative research approach was chosen because, according to Richardson (1996), it is predominantly relevant to understand complex situations in which issues need to be revealed as the people involved in the situation experience them. Furthermore, according to Tzabar Ben-Yehoshua (2001), a qualitative research is appropriate in order to understand social phenomena from people's opinions and perceptions. Therefore, this approach was found to be the most suitable for our research.

\section{Research Population}

Since this research sought to gather information on cross-cultural issues involved in managing a failing Arab local authority organization, nine employees in managerial positions at the Arab local authority under the ruling of an appointed committee agreed to provide data.

\section{Research Tools}

Semi-structured interviews were used to gather information in order to understand the phenomenon under investigation. According to Creswell (2012), semi-structured interviews can help collecting the data as they allowed for generating insights, thoughts and provided an opportunity to describe activities that are directly related to the researched issues. The interviews were conducted as conversations, and included questions that touched upon predetermined major issues that were congruent with the research questions (Creswell, 2012). The data were collected during the year 2014 .

\section{Data Analysis}

Content analysis was used to analyze the data collected, while the units of analysis were words or phrases as they pertained to the research aims, questions, and the researched issue. The analysis process began with an initial mapping stage, during which various interviewees' statements were compared for the purpose of identifying similarities and differences inductively. Similar statements were joined together under the same category 
Issue no. $24 / 2017$

according to contents (Shkedi, 2011). The categorization process was conducted as interpretation and conceptualization, meaning, creating a system of concepts that would provide meaning to the data.

\section{Findings}

The content analysis that was employed on the data collected from employees in managerial positions at the Arab local authority yielded three themes and nine categories. The findings are presented according to the emerging themes and their respective categories.

\section{Theme 1: Expectations and Role Perceptions}

\begin{tabular}{|l|l|}
\hline Category & Evidence \\
\hline Expectations & $\begin{array}{l}\text { I demand and expect from the Council in charge to } \\
\text { facilitate public services and bring them to the village } \\
\text { as certain medical services or the establishment of } \\
\text { academic education institutions, }\end{array}$ \\
\hline Role perceptions & $\begin{array}{l}\text { The wise committee chairman will leverage the } \\
\text { community between the two cultures, and establish a } \\
\text { management team of the local village council }\end{array}$ \\
\hline
\end{tabular}

\section{Expectations}

The evidence shows that the residents of the Arab local authority have a number of expectations of the appointed committee. For example, A said that: I demand and expect from the Council in charge to facilitate public services and bring them to the village as certain medical services or the establishment of academic education institutions. The expectations are expressed in terms of 'demands', and relate to expectations to rehabilitate the public services that enable normal life, such as medical and educational services. Moreover, the residents expect the appointed committee to run the village in the highest quality possible, so that, in the words of $\mathrm{A}$, the residents can enjoy 'medical services that are 
Issue no. $24 / 2017$

still far away, and job opportunities that are limited, because the village is located in the periphery'. It can be said, then, that the appointed committee is perceived as an opportunity to resume normal life including upgrading public services.

\section{Role perceptions}

In addition to the expectations of appointed committees assigned to rehabilitate a failing Arab local authority, another category that emerged illustrates the role perceptions of the committee. In the words of $\mathrm{B}$, 'The wise committee chairman will leverage the community between the two cultures, and establish a management team of the local village council'. According to the evidence, the chairman of the appointed committee who belongs to a different culture is perceived as having the wisdom to raise the level of the community by including local residents to join the management team and bring the local authority to a reasonable function. It can be said, then, that the role of the appointed committee within an intercultural context is perceived as bridging the cultural gap and resuming the management of the local authority by local members.

\section{Theme 2: Ambivalence}

The content analysis that was employed to understand the cross-cultural issues involved in managing a local authority within an intercultural context yielded two categories - difficulties as well as benefits.

\begin{tabular}{|c|c|}
\hline Category & Evidence \\
\hline Difficulties & No cooperation from the residents and the local leaders. \\
\hline Advantages & $\begin{array}{r}\text { The difference of nationality can positively influence the } \\
\text { committee chairman who comes from a different culture and } \\
\text { a different management culture- } \\
\text { Another origin mayor with the villagers can create great } \\
\text { work and the circuit more efficient- } \\
\begin{array}{r}\text { Some areas are not influenced by the chairman's origin such } \\
\text { as infrastructure and engineering, and other matters that are } \\
\text { done following certain rules. }\end{array}\end{array}$ \\
\hline
\end{tabular}


Issue no. $24 / 2017$

\section{Difficulties}

The evidence gathered shows the difficulties associated with the work of the appointed committee, mostly relating to reluctance to cooperate with the local leaders and committee members. According to $\mathrm{C}$, 'there was no cooperation from the residents and the local leaders'. Additionally, according to D., 'every family wants that the head of the local authority will be one that belongs to them, therefore, there is always resistance coming from the other families'. In other words, the difficulties are related to the traditional struggles within Arab communities on the leadership. Another interviewee, E, said that "when the village is run by a foreign body that is not familiar with our culture and our people or our place, it will take quite some time until it will get into the atmosphere of the place. Then the committee will start working by the will of the residents and not by strict criteria that are not appropriate to our arena'. Again, the difficulties are expressed in terms of the culture gap and are associated with the fact that the committee is perceived as a 'foreign body' to the local culture.

\section{Benefits}

According to the interviewees, there are benefits to an appointed committee in the process of rehabilitating a failing Arab local authority within an intercultural context. According to A., 'on the other hand, the difference in nationality can bring about a positive influence because the chair of the appointed committee coming from a different culture will bring with him another culture, and will know how to leverage the village'. A similar view was expressed by $\mathrm{C}$ who said that 'Another origin mayor with the villagers can create great work and the outcome will be more efficient'. In other words, the chair is perceived as a manager who has no political aspirations regarding leading the community, and therefore, does not embody any competition to the local leaders. Hence, the work of the appointed committee is perceived as purely for the benefit of the villagers' needs, so the work of the appointed committee has a fair chance to be efficient.

Support for this view was gained from $\mathrm{E}$ who said that there is an advantage in a chairperson from another culture because 'Some areas are not influenced by the chairman's 
Issue no. 24/2017

origin such as infrastructure and engineering, and other matters that are done following certain rules'.

In sum, it seems that the work of an appointed committee within an intercultural context is perceived as an ambivalent process, including difficulties as well as benefits that stem from the cultural differences.

\section{Theme 3: Cross-Cultural Issues}

The cross-cultural issues that emerged from the content analysis relate to four categories, i.e., a common language, communication, democracy, and culture gap.

\begin{tabular}{|c|c|}
\hline Category & Sample Evidence \\
\hline A common Language & $\begin{array}{l}\text { If he speaks in the same language he will not have difficulties } \\
\text { in communicating with the public around him, the media is a } \\
\text { very important criterion for cooperation between the } \\
\text { residents and of the Council }\end{array}$ \\
\hline Communication & $\begin{array}{l}\text { A chair of an appointed committee who comes from another } \\
\text { culture will find it difficult to communicate with the local } \\
\text { people. }\end{array}$ \\
\hline Democracy & $\begin{array}{l}\text { And when the council is ready, they appoint someone from } \\
\text { the village } \\
\text { It must be built with the continuing local Council, namely, to } \\
\text { build a future generation of residents of the community, } \\
\text { integrating them into the management council appointed to } \\
\text { finish the task and continue for the proper management and } \\
\text { development in all democratic aspects. }\end{array}$ \\
\hline Culture Gap & $\begin{array}{l}\text { It is a disadvantage that he (the chair of the appointed } \\
\text { committee) does not know the local culture } \\
\text { There is no doubt that the different origin of the Committee } \\
\text { can interfere because of the lack of knowledge of the local } \\
\text { and its preferences. }\end{array}$ \\
\hline
\end{tabular}


Issue no. $24 / 2017$

\section{A Common Language}

The evidence gathered for this study yielded language as a central issue related to cross-cultural contexts. According to $\mathrm{C}$, 'If he (the chairperson of the appointed committee) speaks in the same language he will not have difficulties in communicating with the public around him'. Moreover, a common language allows for cooperation, as can be seen in the words of E: 'the language is a very important criterion for cooperation between the residents and of the appointed committee'. In other words, language as a critical concept within an intercultural context is the key for cooperation, probably because it allows for direct communication with the residents, which can facilitate the rehabilitation of the failing Arab local authority.

\section{Communication}

Associated with language is communication as a key factor in managing the failing Arab local authority in Israel. In the words of A., 'A chair of an appointed committee who comes from another culture will find it difficult to communicate with the local people'. As stated previously, direct communication with the local residents can allow for exchange of views, for expressing feelings and ideas, thus allowing for the committee to fulfil its aims for the benefit of the local residents.

\section{Culture Gap}

The data gathered through the interviews yielded culture gap as a central issue in managing a failing Arab local authority within an intercultural context. Evidence can be seen in the words of A who said that 'It is a disadvantage that he (the chair of the appointed committee) does not know the local culture'. Moreover, 'There is no doubt that the different origin of the Committee can interfere because of the lack of knowledge of the locals and their preferences'. In other words, when the appointed committee is chaired by a person who is foreign to the local culture, a gap is created which interferes with the management of a failing Arab local authority within an intercultural context. 
Issue no. $24 / 2017$

\section{Democracy}

The data gathered from the participants in this study show that the ultimate goal of the appointed committee is to restore the democratic rights of the local authority residents. The participants expressed this wish clearly when they said that (D): 'And when the committee is ready, they appoint someone from the village'. In other words, the committee is required to identify a person from the village to whom the reins will be passed in order to resume the local authority's ruling. Moreover, 'It must be built with the continuing local council namely, to build a future generation of residents of the community, integrating them into the management council appointed to finish the task and continue for the proper management and development in all democratic aspects'. In other words, an integral part of the appointed committee's aims is the need to ensure that the democratic rights of the local residents are restored by maintaining a proper management of the local authority as the appointed committee's task is over, and providing supervision and accompaniment.

\section{Discussion and Conclusions}

This research on cross-cultural issues involved in managing a failing Arab local authority in Israel has indicated the need to address the culture gap that is created in this intercultural context. As maintained by Beeri and Kohel (2009), appointing a committee to rehabilitate a failing local authority is not an ideal or natural step, but still it bears potential to heal the authority. The findings that emerged from this modest research show the high expectations of the appointed committee to manage the failing Arab organization, higher than those assumed to the failing local authority itself. Additionally, the findings portray an ambivalent picture of the appointed committees' work within a cross-cultural context. On the one hand the process seems beneficial because of the opportunity to resume normal life including upgrading public services. However, on the other hand, the committee is perceived as a 'foreign body' that creates a culture gap which impedes cooperation with the local residents. Furthermore, the culture gap is due to lack of common language and communication, which in return impedes negotiation processes that are necessary for proper public organization management. In a cross-cultural situation, where the parties are different 
in their language, religion and culture, intercultural communication is necessary in order to allow for exchanging ideas and views in a respectful manner (Puscas, 2009).

The findings further show that the role of the appointed committee within a crosscultural context is to bridge this cultural gap and to resume the management of the local authority by local members. Ultimately, the committee is expected to restore the democratic rights of the local residents by maintaining a proper management of the local authority as the appointed committee's task is over, and to ensure continuity of quality local authority management (Ben-Bassat \& Dahan, 2008).

In conclusion, awareness of the difficulties in bridging the cultural gap as well as of the advantages in managing the failing local authority by an effective appointed committee will facilitate the acceptance of leadership from another culture. Furthermore, it seems necessary to manage negotiation processes with the local residents while adopting intercultural processes based on a common language and communication and with the promise to restore the democratic rights of the residents. Finally, an intercultural negotiation management will allow for identifying failures and obstacles in the performance of a local authority early on, enable the development of appropriate intervention tools, provide help that may lead to significant recovery and change, encourage a productive organizational culture and prevent the recurrence of periodical crises in local authorities which are not equipped with sufficient forces for recovery.

As for a future research, it seems worthwhile to investigate the situation after the committee finished its term, and to examine whether supervision and accompaniment are provided and to what extent.

\section{Bibliography}

1. BEERI, I. (2009). Recovery of Poor Performing Municipalities in Israel: A Comparative Perspective in Light of the British Experience. Floersheimer Institute for Policy Studies, Hebrew University: Jerusalem (In Hebrew) 
Issue no. $24 / 2017$

2. BEERI, I. and KOHEL, A. (2009). Guide to the Chairman of the appointed committee in the Local authority. Jerusalem: ministry of Interior.

3. BEN-BASSAT, A. and DAHAN, M. (2008). The Crisis in Local Governments in Israel Efficiency versus Representation. The Israel Democracy Institute: The Eli Hurvitz Conference on Economy and Society (Caesarea Forum), Jerusalem (In Hebrew)

4. BEN-ELIA, N. (2006). Performance Measures in Local Government - Steps for the Development of Local Government and Administration. Ministry of Interior - The Administration for Local Government and Administration (In Hebrew)

5. CHRISTENSEN T., LAEGREID, P. \& STIGEN, I. M., (2004). Performance Management and Public Sector Reform: The Norwegian Hospital Reform, A working paper written as part of the research project: Autonomy, Transparency and ManagementThree Reform Programs in Health Care (ATMhelth) at the Stein Rokkan Center for Social Research.

6. CRESWELL, J. W. (2012). Research Design: Qualitative, Quantitative, and Mixed Methods Approaches. Thousand Oaks, CA: Sage

7. GRINYER, P. H., MAYERS, D. G. \& McKIERAN, P. (1990). The Sharpbenders: Achieving a Sustained Improvement in Performance, Long Range Planning, 23: 116.

8. MELLAHI, K. \& WILKINSON, A. (2004). Organizational Failure: A Critique of Recent Research and a Proposed Integrative Framework, International Journal of Management Reviews, Volume 5-6, Issue 1, pages 21-41, March 2004

9. PUSCAS, V., 2009, Intercultural communication in managing global interdependence, lecture presented in the International Congress on "Soft Power", cultural diplomacy and interdependence, $\quad$ November 2009, Berlin http://www.culturaldiplomacy.org/academy/content/articles/speakers/detailed/vasilepuscas/8.5.2016

10. RICHARDSON, V., (1996). The Role of Attitudes and Beliefs in Learning to Teach. In J. SIKULA, (ed.). Handbook of research on teacher education. (Pp.102-119). New York: Macmillan,

11. SABAR BEN-YEHOSHUA, N. (2001). Genres and traditions in qualitative research. Lod: Dvir 
12. SCHENDEL, D., PATTON, G. R. \& RIGGS, J., (1975). Corporate Turnaround Strategies: A Study of Profit, Decline and Recovery, Journal of General Management, 33,3

13. SHKEDI, A. (2011). The Meaning behind the Words, Methodologies of Qualitative Research: Theory and Practice. Tel Aviv: Ramot (In Hebrew) 